\title{
Teachers' Perception of Online Teaching during Covid-19: A study at UTAS-Ibra, Oman.
}

\author{
${ }^{1}$ Dr. Kodhandaraman Chinnathambi, ${ }^{2}$ Ms. Latha Anandan, ${ }^{3}$ Dr. B. Thenmalar Bharathi \\ 1,2 Lecturer, English Language Center, University of Technology and Applied Sciences-Ibra, Oman. \\ ${ }^{3}$ Associate Professor, Department of Science and Humanities, \\ RMD Engineering College, Kavaraipettai, Chennai, India.
}

\begin{abstract}
The Covid-19 outbreak led to the closure of educational institutions and affected all the stakeholders in varied ways. As an interim measure, the online mode of teaching has been adopted all over the world. This transition, with its own pros and cons, has provided a path for continuing with education even during the pandemic. This new scenario involves financial and non-financial aspects with regard to education, and there is therefore a need to study the transition carefully.This study aims to explore and describe Teachers' Perception on online teaching. A quantitative research design has been adopted for the study. A structured questionnaire was used $(\mathrm{N}=56)$ for data collection from teachers. The study participants were the teachers at the English Language Centre at the University of Technology and Applied Sciences (Ibra), Sultanate of Oman. The findings of the study confirm that online teaching has been successful during covid-19 outbreak.
\end{abstract}

Keywords: Covid-19, online teaching, challenges, participation, teaching platforms.

\section{Introduction}

By August 2020, the cumulative cases of Covid-19 had reached about 20 million globally as per the statistics circulated by the World Health Organization. This alarming surge in incidence kept many countries on red alert. Educational institutions in different parts of world had to resort to a new mode of online teaching and learning. The current covid-19 outbreak has brought about a transition from face-to-face classes to online classes, marking a profound transformation in the way both educators and students approach the teachinglearning process. According to a report from UNESCO, there are about 290.5 million students who have been affected across the globe.The impact of the lockdown on the environment has been positive. Research points out that "the lockdown acts as a healing dose for climate change, ozone depletion, human health, brown haze etc” (Verma, p7356). 
However, there has been a strong negative impact on the global economy. Many countries have employed fiscal policy measures to mitigate the negative impact of Covid-19 and to stabilize the economy.

Globally, the stakeholders in higher education are facing challenges on multiple fronts. Educational institutions are trying their best to escape the financial crunch caused by the pandemic. Against this backdrop, the transition from face-to-face classes to online classes has the potential, due to the shortfall in technical and pedagogical skills on the part of the teachers and problems with regard to access to digital devices and internet connectivity for the students, to affect the quality of online education. In addition, this is likely to accentuate existing disparities among students because of the differing access to the digital devices and networks that are meant to deliver teaching to their homes. This inequality can have a negative impact on the economy of a country in the longer term. Research carried out in different countries across the globe confirm that this disparity exists across all categories of stakeholders-- teachers, students, and institutions. The results of research studies carried out by the Harvard School of Education in 98 countries, and by the World Bank throw up examples of these disparities.

Oman, like other countries, has closed down educational institutions and shifted to online teaching as a precautionary measure. Restrictions on internal movements and enforcement of social distancing are employed to bring down the spread of covid-19. These measures coupled with oil price shocks, have considerably affected the economic activities of the country.

\section{Literature Review}

The impact of Covid-19 on education has to be examined with utmost care by the educators. Although online teaching is just a temporary arrangement during the pandemic outbreak, the transition has created a new disadvantaged group. Thomas and Rogers (2020) point out that "the requirement for children to continue their studies at home may exacerbate differences in the educational progress caused by inequalities. Children from homes with fewer resources and less opportunity for parental support risk falling behind, widening preexisting gaps.” Similarly, unsupportive parents and unconducive home environments also play a role in widening the gap. Daniel points out that "parents and guardians may be deeply anxious about their own economic future, so studying at home is not easy, especially for children with low motivation. Such homes often lack the equipment and connectivity that 
richer households take for granted, compounding the problem (Daniel, p2)” In addition, the following factors have the potential to widen the existing inequality, (a) the gap between schools that provide students with good digital infrastructure and schools that do not, (b) the gap between schools that have technically skilled teachers who can integrate technology in their teaching and teachers who lack such skills, (c) disparity in cognitive and non-cognitive skills. In addition, "in the absence of appropriate policy measures, the short-term inequality caused by COVID-19 may persist or even grow over time, leading to more economic disparity in the future (Pietro etal, p4)." In addition to the learning gap, students also experience learning loss. “Conservative’ estimates for France, Italy and Germany suggest that students will suffer a weekly learning loss of between 0.82 and $2.3 \%$ of a standard deviation. Such loss reflects the reduction in test scores that students would experience because of less time spent in online learning compared to the amount of time they typically invest when they are in school (Pietro etal, p7)” Hence, the learning gap and learning loss can affect both the students and the country negatively.

"The national lockdown of educational institutions as a result of COVID-19 pandemic in Nigeria and across the World is going to cause major interruption in students' learning; disruptions in academic programme, suspension of examination, cancellation of internal and international conferences, creating gap in teaching and learning and probably may cause manpower shortage in the institutions as a result of death caused by COVID-19” (Jacob etal, p8). Reimer and A. Schleicher identify “differences among students in support from parents who can provide for them educational opportunities directly at home or accessing them privately, differences in the capacity of different types of schools to support the learning of their students remotely, and differences among students in their resilience, motivation and skills to learn independently and online (p4)”and warns that these gaps can widen the existing disparities. His research also concludes that the COVID-19 Pandemic is "likely to generate the greatest disruption in educational opportunity worldwide in a generation. This disruption will impact the livelihoods of individuals, and the prospects of their communities (Reimers, p4)." According to the report Learning at home during COVID-19: Effects on vulnerable young Australians, about " $46 \%$ of the student population are vulnerable to adverse effects on their educational outcomes, nutrition, physical movement, social and emotional wellbeing by being physically disconnected from school (Brown, p5).” As very few research studies have been carried out and published in the context of the situation in Oman, this paper attempts to 
study the extent to which online learning had widened the existing disparities among the students.

\section{Objective and Hypothesis}

The aim of the study is to investigate Teachers' perception on online teaching during Covid-19 outbreak at UTAS-Ibra. Five hull hypotheses were formulated to study Teachers' Perception.

1) There is no significant difference between Mean Rank of Two Factors of Perception of teachers on online teaching during Covid-19 outbreak. (Mann Whitney Test)

2) There is no significant difference between mean ranks of Two Factors of Perception of teachers on online teaching during Covid-19 outbreak. (Wilcoxon Test)

3) There is no relationship between Factors of Perception of teachers on online teaching during Covid-19 outbreak.

4) Level of Perception of Teachers on online teaching during Covid-19 is equally distributed.

5) There is no association between Gender and Level of Perception of Teachers on online teaching during Covid-19 outbreak.

\section{Scope of the study}

The abrupt transition from face-to-face teaching to online teaching has affected all the stakeholders and the quality of teaching and learning across the globe. Hence, this study intends to measure the impact of online teaching on the quality of teaching of teachers in the University of Technology and Applied Sciences in Oman. The findings of the study will significantly contribute to the administration and the teachers to identify and mitigate the negative factors that exist currently in the online mode of teaching. As the covid-19 pandemic is the new normal in all the countries, the findings will help Higher Education Institutions in Oman and in other countries to provide a better quality of education.

\section{Research Methodology}

Primary data were collected through questionnaires, and the secondary data through Google scholar and Pro Quest. The participants of the study were the teachers who teach General Foundation Program and Post Foundation Program at the ELC, University of 
Technology and Applied Sciences-Ibra, Oman. The respondents were both Male and Female with different Age Group, different Nationalities, and different levels of teaching at the General Foundation Program of UTAS-Ibra. Out of the 81 teachers, 55 sent in responses.

The study employed Random Sampling Technique. A self-designed questionnaire was prepared using Google forms with three types of questions such as (1) Dichotomous, (2) MCQs using Likert Scale, and (3) Open ended. The data were collected and analyzed using Random Sampling Technique. The methods employed for data analysis were non-parametric tests such as Mann Whitney test, Wilcoxon test, Spearman Correlation test, and Chi-Square test. Google forms was used as a tool to collect responses from the participants and Statistical Package for Social Sciences (SPSS) was used for data analysis.

\section{Analyses and Interpretation}

Descriptive analysis

Table 1: Frequency Table for Gender Category

\begin{tabular}{|c|c|c|c|c|c|}
\hline \multicolumn{6}{|c|}{ Gender: } \\
\hline & & Frequency & Percent & Valid Percent & Cumulative Percent \\
\hline \multirow{3}{*}{ Valid } & 1 & 29 & 52.7 & 52.7 & 52.7 \\
\hline & 2 & 26 & 47.3 & 47.3 & 100.0 \\
\hline & Total & 55 & 100.0 & 100.0 & \\
\hline
\end{tabular}

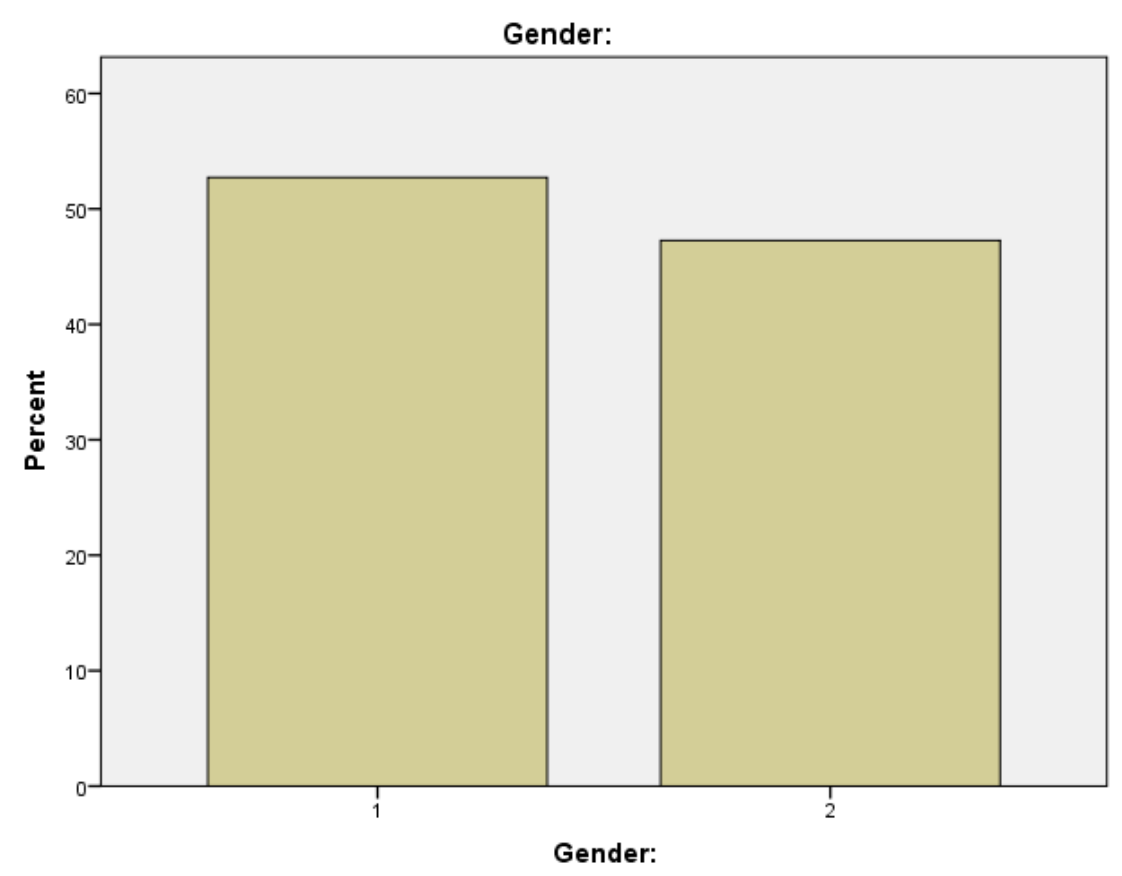


Figure 1:1 Bar Chart Representation of Respondents by Gender Category

From the above table, $52.7 \%$ of respondents are Males and $47.3 \%$ are Females. In this data collection most of the respondents are Males because the English language Centre holds a record of a greater number of male teachers than female teachers over the years and male teachers prefer to stay in the jobs longer as they find their jobs satisfactory.

Table 2 Frequency distribution of Respondents by Age Category

\begin{tabular}{|c|c|c|c|c|c|}
\hline \multicolumn{2}{|c|}{ Age: } \\
\hline \multirow{3}{*}{} & Frequency & Percent & Valid Percent & $\begin{array}{c}\text { Cumulative } \\
\text { Percent }\end{array}$ \\
\hline \multirow{7}{*}{ Valid } & 0 & 1 & 1.8 & 1.8 & 1.8 \\
\cline { 2 - 7 } & 1 & 17 & 30.9 & 30.9 & 32.7 \\
\cline { 2 - 7 } & 2 & 22 & 40.0 & 40.0 & 72.7 \\
\cline { 2 - 7 } & 3 & 15 & 27.3 & 27.3 & 100.0 \\
\cline { 2 - 7 } & Total & 55 & 100.0 & 100.0 & \\
\hline
\end{tabular}

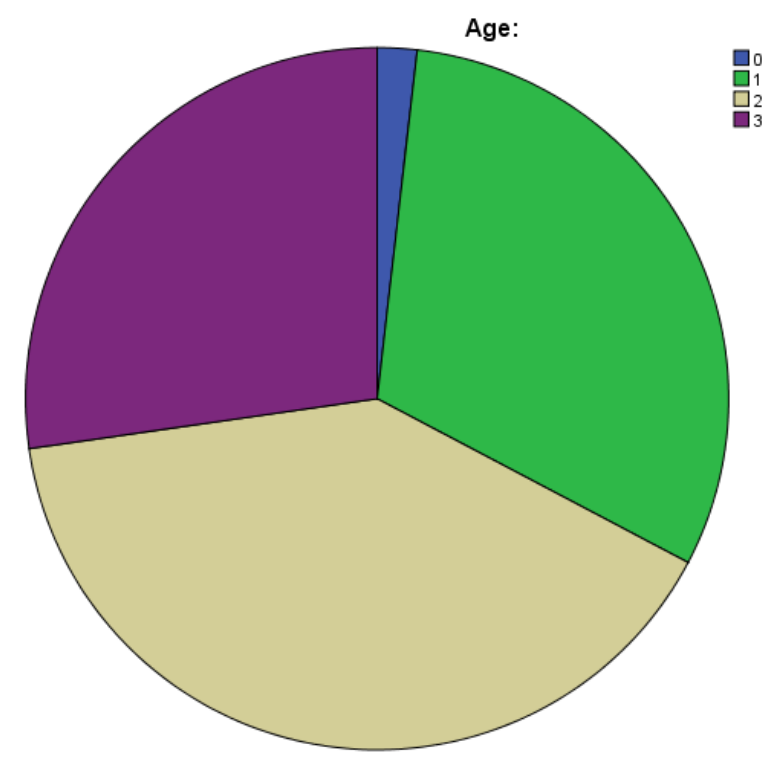

Figure 1.2 Pie Diagram Representation of Respondents by Age Category

From the above table, $40 \%$ of respondents are in the $40-49$ age group, $30.9 \%$ are in the 30 -39 age group, $27.3 \%$ are in the 50 and above age group and $1.8 \%$ are in the $20-29$ age group. Maximum number of respondents are between 40-49 and 30-39 age groups and minimum number of respondents are between 50 and above and 20-29 age groups. This is 
because teachers who are 50 and above are mostly expatriates and they have been working in this university for a long period of time. The youngest group has only one teacher who joined the university recently. The other two groups where the percentage is more are teachers who are working here for more than 5 to 10 years.

Table 3: Frequency Distribution of Respondents by Nationality

\begin{tabular}{|c|c|c|c|c|c|}
\hline \multicolumn{5}{|c|}{ Nationality: } \\
\hline \multirow{3}{*}{} & Frequency & Percent & Valid Percent & Cumulative Percent \\
\hline \multirow{3}{*}{ Valid } & 1 & 5 & 9.1 & 9.1 & 9.1 \\
\cline { 2 - 6 } & 2 & 50 & 90.9 & 90.9 & 100.0 \\
\cline { 2 - 6 } & Total & 55 & 100.0 & 100.0 & \\
\hline
\end{tabular}

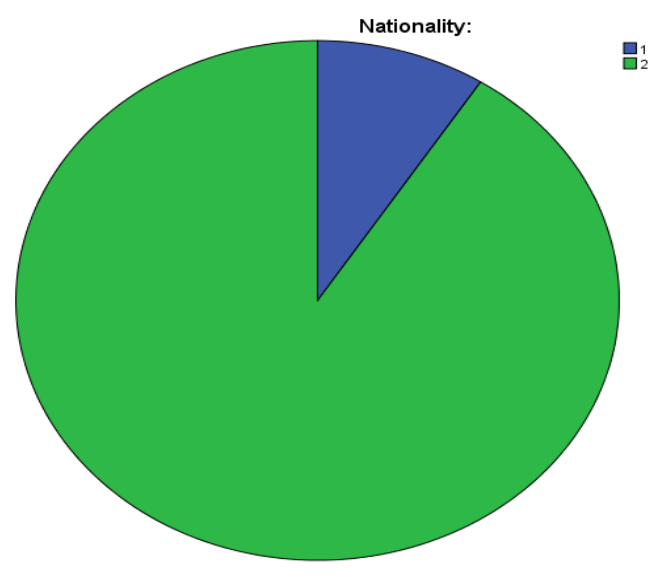

Figure 1:3 Pie Diagram Representation of Respondents by Nationality

From the above table, $90.9 \%$ of respondents are expatriates and $9.1 \%$ are Omanis. This is because government recognized recruitment companies hire teachers who satisfy the criteria specified by the Ministry of Manpower from outside the country. On the other hand, the percentage of qualified teachers within the country is very low. So, it is a case of demand and supply. Thus, we find more expatriate teachers working at the university. 
Table 4: Frequency Distribution of Respondents by Levels Taught

\begin{tabular}{|c|c|c|c|c|c|}
\hline \multicolumn{7}{|c|}{ Levels Taught } \\
\hline \multirow{7}{*}{} & Frequency & Percent & Valid Percent & $\begin{array}{c}\text { Cumulative } \\
\text { Percent }\end{array}$ \\
\hline \multirow{7}{*}{ Valid } & 1 & 12 & 21.8 & 21.8 & 21.8 \\
\cline { 2 - 6 } & 2 & 12 & 21.8 & 21.8 & 43.6 \\
\cline { 2 - 6 } & 3 & 9 & 16.4 & 16.4 & 60.0 \\
\cline { 2 - 6 } & 4 & 15 & 27.3 & 27.3 & 87.3 \\
\cline { 2 - 6 } & 5 & 7 & 12.7 & 12.7 & 100.0 \\
\cline { 2 - 6 } & Total & 55 & 100.0 & 100.0 & \\
\hline
\end{tabular}

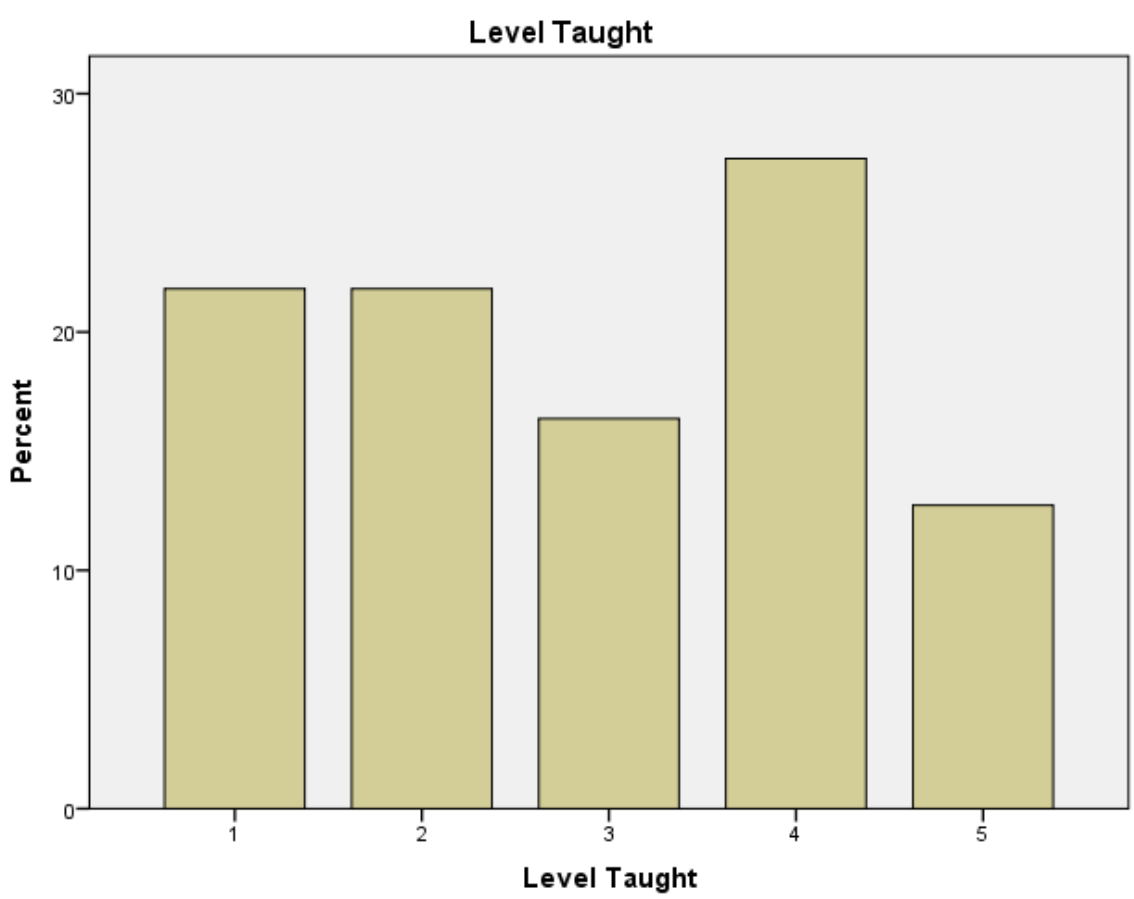

Figure 1:4 Bar Chart Representation of Respondents by Levels Taught

From the above table, $27.3 \%$ of respondents teach Level 4, $21.8 \%$ of respondents teach level 1 and 2 respectively,16.4\% of respondents teach Level 3 and 12.7\% of respondents teach Level 5 (Post Foundation PF). Teachers are placed in their respective levels based on the number of groups and student enrollment per level. Thus, the number of respondents from Level 3 and Level 5 are minimum compared to all the other levels. 


\section{HYPOTHESIS I}

Null Hypothesis: There is no significant difference between Mean Rank of Two Factors of Perception of teachers on online teaching during Covid-19 outbreak.

Table 1.Mann Whitney test for significant difference between Mean Rank of two Factors of Perception of teachers on online teaching during Covid-19 outbreak

\begin{tabular}{|c|c|c|c|c|}
\hline \multicolumn{5}{|c|}{ Ranks } \\
\hline & Gender: & $\mathbf{N}$ & Mean Rank & Sum of Ranks \\
\hline \multirow{3}{*}{ Student Participation } & Male & 29 & 25.55 & 741.00 \\
\hline & Female & 26 & 30.73 & 799.00 \\
\hline & Total & 55 & & \\
\hline \multirow{3}{*}{ Teacher Participation } & Male & 29 & 28.48 & 826.00 \\
\hline & Female & 26 & 27.46 & 714.00 \\
\hline & Total & 55 & & \\
\hline \multirow{3}{*}{ Online Platform } & Male & 29 & 31.09 & 901.50 \\
\hline & Female & 26 & 24.56 & 638.50 \\
\hline & Total & 55 & & \\
\hline \multirow{3}{*}{ College support } & Male & 29 & 27.16 & 787.50 \\
\hline & Female & 26 & 28.94 & 752.50 \\
\hline & Total & 55 & & \\
\hline \multirow{3}{*}{ Perception of Online Teaching } & Male & 29 & 29.19 & 846.50 \\
\hline & Female & 26 & 26.67 & 693.50 \\
\hline & Total & 55 & & \\
\hline
\end{tabular}

\begin{tabular}{|l|c|c|c|c|c|}
\hline \multicolumn{7}{|c|}{ Test Statistics $^{\text {a }}$} \\
\hline & $\begin{array}{c}\text { Student } \\
\text { Participation }\end{array}$ & $\begin{array}{c}\text { Teacher } \\
\text { Participation }\end{array}$ & $\begin{array}{c}\text { Online } \\
\text { Platform }\end{array}$ & $\begin{array}{c}\text { College } \\
\text { support }\end{array}$ & $\begin{array}{c}\text { Perception on } \\
\text { Online } \\
\text { Teaching }\end{array}$ \\
\hline Mann-Whitney U & 306.000 & 363.000 & 287.500 & 352.500 & 342.500 \\
\hline Wilcoxon W & 741.000 & 714.000 & 638.500 & 787.500 & 693.500 \\
\hline Z & -1.238 & -.237 & -1.515 & -.419 & -.582 \\
\hline $\begin{array}{l}\text { Asymp. Sig. (2- } \\
\text { tailed) }\end{array}$ & .216 & .813 & .130 & .675 & .560 \\
\hline a. Grouping Variable: Gender: & & & & \\
\hline
\end{tabular}


$\mathrm{P}$ value is greater than 0.05 .So, the null hypothesis is accepted at $5 \%$ level of significance. Hence, from the data we can conclude that there is no significant difference between Factors and Mean Rank of Male and Female. It is clear from the above table that there is no significant relationship between Gender and Student Participation, Gender and Teacher Participation, Gender and Online Platform, Gender and College Support and Gender and Teachers’ Perception on Online Teaching.

\section{HYPOTHESIS II}

Null Hypothesis: There is no significant difference between mean ranks of Two Factors ofPerception of teachers on online teaching during Covid-19 outbreak.

Table 1.2 Wilcoxon test for significant difference between mean ranks of two Factors of

Perception of teachers on online teaching during Covid-19 outbreak.

\begin{tabular}{|c|c|c|c|c|}
\hline \multicolumn{5}{|c|}{ Ranks } \\
\hline & & $\mathbf{N}$ & Mean Rank & Sum of Ranks \\
\hline \multirow{4}{*}{$\begin{array}{l}\text { Teacher Participation - } \\
\text { Student Participation }\end{array}$} & Negative Ranks & $0^{\mathrm{a}}$ & .00 & .00 \\
\hline & Positive Ranks & $55^{b}$ & 28.00 & 1540.00 \\
\hline & Ties & $0^{\mathrm{C}}$ & & \\
\hline & Total & 55 & & \\
\hline \multirow{4}{*}{$\begin{array}{l}\text { Online Platform - Teacher } \\
\text { Participation }\end{array}$} & Negative Ranks & $55^{d}$ & 28.00 & 1540.00 \\
\hline & Positive Ranks & $0^{\mathrm{e}}$ & .00 & .00 \\
\hline & Ties & $0^{f}$ & & \\
\hline & Total & 55 & & \\
\hline \multirow{4}{*}{$\begin{array}{l}\text { College support - Teacher } \\
\text { Participation }\end{array}$} & Negative Ranks & $55^{g}$ & 28.00 & 1540.00 \\
\hline & Positive Ranks & $0^{\mathrm{h}}$ & .00 & .00 \\
\hline & Ties & $0^{i}$ & & \\
\hline & Total & 55 & & \\
\hline \multirow{4}{*}{$\begin{array}{l}\text { Perceptionon Online Teaching - } \\
\text { Teacher Participation }\end{array}$} & Negative Ranks & $0^{j}$ & .00 & .00 \\
\hline & Positive Ranks & $55^{k}$ & 28.00 & 1540.00 \\
\hline & Ties & $0^{1}$ & & \\
\hline & Total & 55 & & \\
\hline \multicolumn{5}{|c|}{ a. Teacher Participation < Student Participation } \\
\hline \multicolumn{5}{|c|}{ b. Teacher Participation > Student Participation } \\
\hline \multicolumn{5}{|c|}{ c. Teacher Participation = Student Participation } \\
\hline
\end{tabular}




\begin{tabular}{|l|}
\hline e. Online Platform $>$ Teacher Participation \\
\hline f. Online Platform $=$ Teacher Participation \\
\hline g. College support $<$ Teacher Participation \\
\hline h. College support $>$ Teacher Participation \\
\hline i. College support = Teacher Participation \\
\hline j. Perception on Online Teaching $<$ Teacher Participation \\
\hline k. Perception on Online Teaching $>$ Teacher Participation \\
\hline l. Perception on Online Teaching = Teacher Participation \\
\hline
\end{tabular}

Test Statistics ${ }^{\mathrm{a}}$

\begin{tabular}{|l|c|c|c|c|}
\hline & $\begin{array}{c}\text { Teacher } \\
\text { Participation - } \\
\text { Student } \\
\text { Participation }\end{array}$ & $\begin{array}{c}\text { Online Platform - } \\
\text { Teacher } \\
\text { Participation }\end{array}$ & $\begin{array}{c}\text { College support - } \\
\text { Teacher } \\
\text { Participation }\end{array}$ & $\begin{array}{c}\text { Perception on } \\
\text { Online Teaching - } \\
\text { Teacher } \\
\text { Participation }\end{array}$ \\
\hline Z & $-6.459^{\mathrm{b}}$ & $-6.456^{\mathrm{C}}$ & $-6.461^{\mathrm{C}}$ & $-6.455^{\mathrm{b}}$ \\
Asymp. Sig. (2-tailed) & .000 & .000 & .000 & .000 \\
\hline
\end{tabular}

a. Wilcoxon Signed Ranks Test

b. Based on negative ranks.

c. Based on positive ranks.

$\mathrm{P}$ value is less than 0.001 . So, the null hypothesis is rejected at $1 \%$ level of significance. From the data, it is inferred that there is a significant difference between Factors and Mean Ranks. It is clear from the above table that there is a significant difference between the Mean Ranks of Teacher Participation and Student Participation, Online Platform and Teacher Participation, College Support and Teacher Participation and Teachers’ Perception on Online Teaching and Teacher Participation.

\section{Hypothesis III}

Null Hypothesis: There is no relationship between Factors ofPerception of teachers on online teaching during Covid-19 outbreak. 
Table 1.3 Spearman's Correlation Coefficient between Factors of Perception of teachers on online teaching during Covid-19 outbreak

\begin{tabular}{|c|c|c|c|c|c|c|}
\hline \multicolumn{7}{|c|}{ Correlations } \\
\hline & & & $\begin{array}{c}\text { Student } \\
\text { Participation }\end{array}$ & \begin{tabular}{|c|} 
Teacher \\
Participation
\end{tabular} & \begin{tabular}{|c|} 
Online \\
Platform
\end{tabular} & $\begin{array}{l}\text { College } \\
\text { support }\end{array}$ \\
\hline \multirow{12}{*}{$\begin{array}{l}\text { Spearman's } \\
\text { rho }\end{array}$} & \multirow{3}{*}{$\begin{array}{l}\text { Student } \\
\text { Participation }\end{array}$} & $\begin{array}{l}\text { Correlation } \\
\text { Coefficient }\end{array}$ & 1.000 & $.331^{*}$ & .249 & .148 \\
\hline & & Sig. (2-tailed) & . & .013 & .067 & .280 \\
\hline & & $\mathrm{N}$ & 55 & 55 & 55 & 55 \\
\hline & \multirow{3}{*}{$\begin{array}{l}\text { Teacher } \\
\text { Participation }\end{array}$} & $\begin{array}{l}\text { Correlation } \\
\text { Coefficient }\end{array}$ & $.331^{*}$ & 1.000 & $.270^{*}$ & $.466^{* *}$ \\
\hline & & Sig. (2-tailed) & .013 & . & .046 & .000 \\
\hline & & $\mathrm{N}$ & 55 & 55 & 55 & 55 \\
\hline & \multirow{3}{*}{$\begin{array}{l}\text { Online } \\
\text { Platform }\end{array}$} & $\begin{array}{l}\text { Correlation } \\
\text { Coefficient }\end{array}$ & .249 & $.270^{*}$ & 1.000 & .188 \\
\hline & & Sig. (2-tailed) & .067 & .046 & . & .170 \\
\hline & & $\mathrm{N}$ & 55 & 55 & 55 & 55 \\
\hline & \multirow{3}{*}{$\begin{array}{l}\text { College } \\
\text { support }\end{array}$} & $\begin{array}{l}\text { Correlation } \\
\text { Coefficient }\end{array}$ & .148 & $.466^{* *}$ & .188 & 1.000 \\
\hline & & Sig. (2-tailed) & .280 & .000 & .170 & . \\
\hline & & $\mathrm{N}$ & 55 & 55 & 55 & 55 \\
\hline
\end{tabular}

Correlation Coefficient between SP and TP is 0.331 which indicates $\left(0.331^{2}=0.3654\right)$ 10.95 percentage positive relationship between SP and TP and is significant at 5\% level. However, it denotes a weak correlation. Although the correlation coefficient between OP and $\mathrm{SP}, \mathrm{CS}$ and SP have a positive relationship, the $\mathrm{p}$ value is greater than 0.05 . Hence there is no significant relationship between SP and OP, SP and CS which denotes that there is no correlation between them.

In the case of the correlation coefficient between TP and CS is 0.466 which indicates $\left(0.446^{2}=0.1989\right) 19.89$ percentage positive relationship between TP and CS and is 
significant at $1 \%$ level. However, the correlation coefficient between TP and OP is 0.270 which indicates $\left(0.270^{2}=0.0729\right) 7.29$ percentage positive relationship between TP and OP and is significant at $5 \%$ level.

In the case of correlation coefficient between OP and CS is 0.188 which indicates $\left(0.188^{2}=0.0353\right) 3.53$ percentage positive relationship between OP and CS and the p value is greater than 0.05 . Hence it is concluded that there is no significant relationship between OP and CS.

\section{HYPOTHESIS IV}

Null Hypothesis: Level of Perception of Teachers on online teaching during Covid-19 is equally distributed.

Table 1.4 Chi-square test for goodness of fit of equality of level of Perception of Teachers on online teaching during Covid-19 outbreak.

\begin{tabular}{|l|r|r|r|}
\hline \multicolumn{5}{|c|}{ Level of Teachers' Perception on online teaching } \\
\hline & \multicolumn{1}{|c|}{ Observed N } & Expected N & Residual \\
\hline Low & 15 & 18.3 & -3.3 \\
\hline Moderate & 26 & 18.3 & -4.3 \\
\hline High & 14 & 18.3 & \\
\hline Total & 55 & & \\
\hline
\end{tabular}

\begin{tabular}{|l|l|}
\hline \multicolumn{2}{|c|}{ Test Statistics } \\
\hline & Level of Teachers' Perception on online teaching \\
\hline Chi-Square & $4.836^{\mathrm{a}}$ \\
\hline Df & 2 \\
\hline Asymp. Sig. & .089 \\
\hline $\begin{array}{l}\text { a. } 0 \text { cells }(0.0 \%) \text { have expected frequencies less than 5. The minimum expected cell } \\
\text { frequency is 18.3. }\end{array}$ \\
\hline
\end{tabular}


$\mathrm{P}$ value is more than 0.05 , so the null hypothesis is accepted at $5 \%$ level of significance. Hence it is clear from the table that the Level of Perception of Teachers on Online teaching is equally distributed. Based on the observed data, majority of teachersbelong to Moderate level (26).

\section{HYPOTHESIS V}

Null Hypothesis: There is no association between Gender and Level of Perception of Teachers ononline teaching during Covid-19 outbreak.

Table 1.5 Chi-square test for association between Genderand Level of Perception of Teachers on online teaching during Covid-19 outbreak

\begin{tabular}{|c|c|c|c|c|c|c|}
\hline \multicolumn{7}{|c|}{ Crosstab } \\
\hline & & & \multicolumn{3}{|c|}{$\begin{array}{c}\text { Level of Teachers' Perception } \\
\text { on online teaching }\end{array}$} & \multirow[t]{2}{*}{ Total } \\
\hline & & & Low & moderate & high & \\
\hline \multirow{8}{*}{ Gender: } & \multirow{4}{*}{ Male } & Count & 7 & 14 & 8 & 29 \\
\hline & & \% within Gender: & $24.1 \%$ & $48.3 \%$ & $27.6 \%$ & $100.0 \%$ \\
\hline & & $\begin{array}{l}\text { \% within Level of } \\
\text { Teachers’ Perception on } \\
\text { online teaching }\end{array}$ & $46.7 \%$ & $53.8 \%$ & $57.1 \%$ & $52.7 \%$ \\
\hline & & $\%$ of Total & $12.7 \%$ & $25.5 \%$ & $14.5 \%$ & $52.7 \%$ \\
\hline & \multirow{4}{*}{ Female } & Count & 8 & 12 & 6 & 26 \\
\hline & & \% within Gender: & $30.8 \%$ & $46.2 \%$ & $23.1 \%$ & $100.0 \%$ \\
\hline & & $\begin{array}{l}\text { \% within Level of } \\
\text { Teachers’ Perception on } \\
\text { online teaching }\end{array}$ & $53.3 \%$ & $46.2 \%$ & $42.9 \%$ & $47.3 \%$ \\
\hline & & $\%$ of Total & $14.5 \%$ & $21.8 \%$ & $10.9 \%$ & $47.3 \%$ \\
\hline \multirow{4}{*}{ Total } & & Count & 15 & 26 & 14 & 55 \\
\hline & & \% within Gender: & $27.3 \%$ & $47.3 \%$ & $25.5 \%$ & $100.0 \%$ \\
\hline & & $\begin{array}{l}\text { \% within Level of } \\
\text { Teachers' Perception on } \\
\text { online teaching }\end{array}$ & $100.0 \%$ & $100.0 \%$ & $100.0 \%$ & $100.0 \%$ \\
\hline & & \% of Total & $27.3 \%$ & $47.3 \%$ & $25.5 \%$ & $100.0 \%$ \\
\hline
\end{tabular}




\begin{tabular}{|l|c|c|c|}
\hline \multicolumn{4}{|c|}{ Chi-Square Tests } \\
\hline & Value & Df & Asymp. Sig. (2-sided) \\
\hline Pearson Chi-Square & $.344^{\mathrm{a}}$ & 2 & .842 \\
\hline Likelihood Ratio & .344 & 2 & .842 \\
\hline Linear-by-Linear Association & .317 & 1 & .573 \\
\hline N of Valid Cases & 55 & & \\
\hline a. 0 cells (0.0\%) have expected count less than 5. The minimum expected count is 6.62. \\
\hline
\end{tabular}

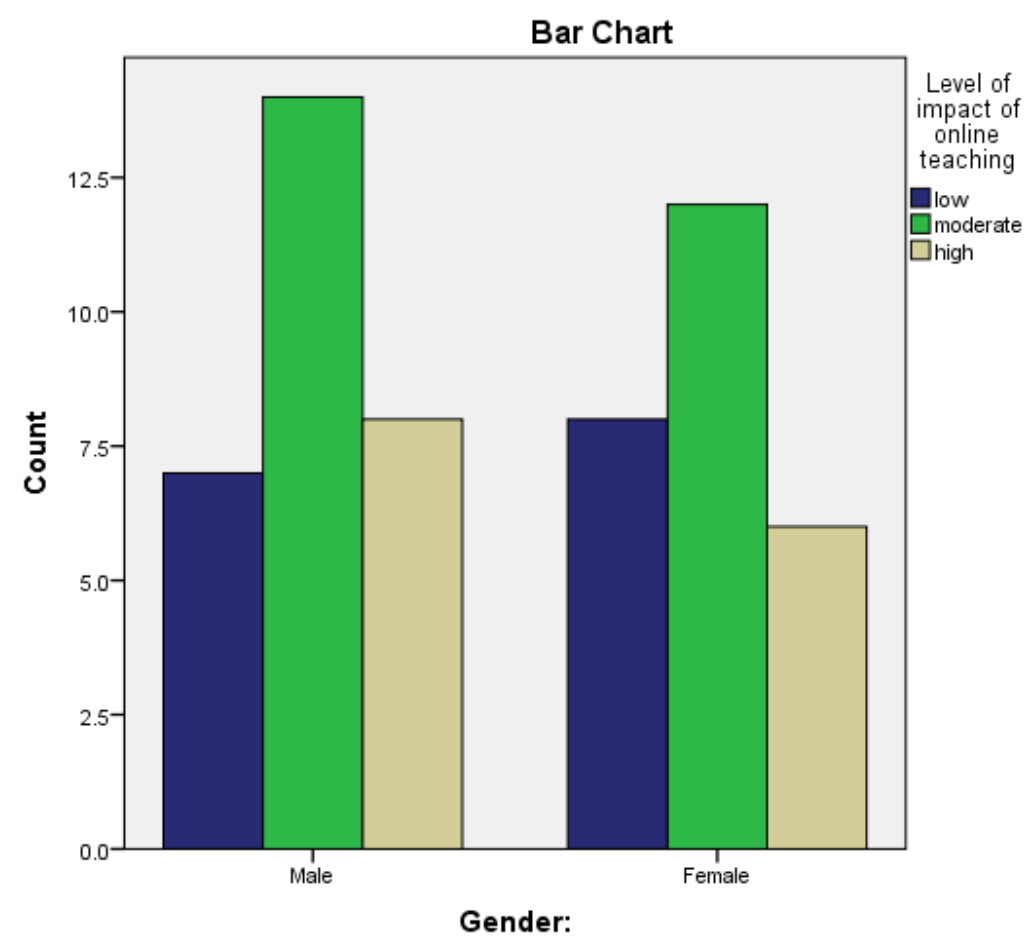

Since $\mathrm{P}$ value is greater than 0.05 , the null hypothesis is accepted at $5 \%$ level of significance. Hence it is concluded thatthere is no association between Gender and Level of Perception of Teachers on online teaching. Based on the row percentage $27.6 \%$ of male shows a high level of agreement in their perception on online teaching whereas $30.8 \%$ of female shows a low level of agreement in their perception on online teaching. Hence it is concluded that majority of male participants show a high level of agreement in their perception on online teaching and majority of female participants show a low level of agreement on online teaching.

\section{Limitation, Conclusion and Recommendation}

The limitation of this study is that the sample data were collected from only one institute in Oman. Therefore, the generalization of the results is limited to only UTAS-Ibra. 
To get exactTeachers' perception of online teaching in Oman, data should be collected from other Higher Educational Institutions in Oman. Hence there is scope for further research in this area.

As per the Mann Whitney test, it is found that there is no significant difference between the study factors. This indicates that gender does not influence any of the study factors. According to Wilcoxon test, there is a significant difference between the mean ranks and study factors. In Spearman's Correlation Coefficient test, there is a significant relationship between some of the study factors. On the other hand, some study factors show no correlation between them. In Chi-square test for goodness of fit of equality, it is found that the level of perception of teachers on online teaching is equally distributed. In Chi-square test for association between two variables using crosstabs, it is found that there is no association between two variables.

The main conclusion of the study is that the abrupt transition from face to face to online teaching has not obstructed teaching and learning.Online teaching has a positive effect on learning. Hence it is recommended that the current practice can be continued and improved.

\section{References:}

1. Reimers, Fernando M., and A. Schleicher. "A framework to guide an education response to the COVID-19 Pandemic of 2020." OECD. Retrieved April 14 (2020): 2020.

2. Di Pietro, Giorgio, et al. The likely impact of COVID-19 on education: Reflections based on the existing literature and recent international datasets. No. JRC121071. Joint Research Centre (Seville site), 2020.

3. Sintema, Edgar John. "Effect of COVID-19 on the performance of grade 12 students: Implications for STEM education." Eurasia Journal of Mathematics, Science and Technology Education 16.7 (2020): em1851

4. Dorn, Emma, et al. "COVID-19 and student learning in the United States: The hurt could last a lifetime." McKinsey \& Company (2020).

5. Toquero, C. M. "Challenges and opportunities for higher education amid the COVID19 pandemic: The Philippine context." Pedagogical Research 5.4 (2020). 
6. Owusu-Fordjour, C., C. K. Koomson, and D. Hanson. "The impact of Covid-19 on learning-the perspective of the Ghanaian student." European Journal of Education Studies (2020).

7. Cullinane, Carl, and Rebecca Montacute. "COVID-19 and Social Mobility Impact Brief\# 1: School Shutdown." (2020).

8. Tran, Trung, et al. "Toward Sustainable Learning during School Suspension: Socioeconomic, Occupational Aspirations, and Learning Behavior of Vietnamese Students during COVID-19." Sustainability 12.10 (2020): 4195

9. Brown, Natalie, et al. "Learning at home during COVID-19: Effects on vulnerable young Australians." (2020).

10. Verma, Ashok, and Sadguru Prakash. "Impact of covid-19 on environment and society." Journal of Global Biosciences 9.5 (2020): 7352-7363.

11. Pajarianto, Hadi, et al. "Study from Home in the Middle of the COVID-19 Pandemic: Analysis of Religiosity, Teacher, and Parents Support Against Academic Stress." Journal of Talent Development and Excellence 12.2s (2020): 1791-1807.

12. Jacob, OgunodeNiyi, I. Abigeal, and A. E. Lydia. "Impact of COVID-19 on the Higher Institutions Development in Nigeria." Electronic Research Journal of Social Sciences and Humanities 2 (2020): 126-135.

13. Hartshorne, Richard, et al. "Special Issue Editorial: Preservice and Inservice Professional Development During the COVID-19 Pandemic." Journal of Technology and Teacher Education 28.2 (2020): 137-147.

14. Azevedo, João Pedro, et al. "Simulating the potential impacts of covid-19 school closures on schooling and learning outcomes: A set of global estimates." (2020). 